\title{
Pulsed electromagnetic energy treatment offers no clinical benefit in reducing the pain of knee osteoarthritis: a systematic review Christopher James McCarthy*1, Michael James Callaghan ${ }^{2}$ and Jacqueline Anne Oldham²
}

\author{
Address: ${ }^{1}$ Warwick Emergency Care and Rehabilitation, Warwick Medical School, University of Warwick, Coventry, CV4 7AL, UK and ${ }^{2 T h e ~ C e n t r e ~}$ \\ for Rehabilitation Science, University of Manchester, Manchester, M13 9WL, UK \\ Email: Christopher James McCarthy* - C.J.McCarthy@warwick.ac.uk; Michael James Callaghan - michael.callaghan@manchester.ac.uk; \\ Jacqueline Anne Oldham - jackie.oldham@manchester.ac.uk \\ * Corresponding author
}

Published: 15 June 2006

BMC Musculoskeletal Disorders 2006, 7:5 I doi: |0.| | 186/|47|-2474-7-5 I

This article is available from: http://www.biomedcentral.com/I47/-2474/7/5 I

(C) 2006 McCarthy et al; licensee BioMed Central Ltd.

This is an Open Access article distributed under the terms of the Creative Commons Attribution License (http://creativecommons.org/licenses/by/2.0), which permits unrestricted use, distribution, and reproduction in any medium, provided the original work is properly cited.
Received: 08 February 2006

Accepted: 15 June 2006

\begin{abstract}
Background: The rehabilitation of knee osteoarthritis often includes electrotherapeutic modalities as well as advice and exercise. One commonly used modality is pulsed electromagnetic field therapy (PEMF). PEMF uses electro magnetically generated fields to promote tissue repair and healing rates. Its equivocal benefit over placebo treatment has been previously suggested however recently a number of randomised controlled trials have been published that have allowed a systematic review to be conducted.
\end{abstract}

Methods: A systematic review of the literature from 1966 to 2005 was undertaken. Relevant computerised bibliographic databases were searched and papers reviewed independently by two reviewers for quality using validated criteria for assessment. The key outcomes of pain and functional disability were analysed with weighted and standardised mean differences being calculated.

Results: Five randomised controlled trials comparing PEMF with placebo were identified. The weighted mean differences of the five papers for improvement in pain and function, were small and their $95 \%$ confidence intervals included the null.

Conclusion: This systematic review provides further evidence that PEMF has little value in the management of knee osteoarthritis. There appears to be clear evidence for the recommendation that PEMF does not significantly reduce the pain of knee osteoarthritis.

\section{Background}

Osteoarthritis is a major health problem affecting over $60 \%$ of adults in the Western world over 65 years of age, yet it receives scant resources for treatment or clinical research $[1,2]$. The knee is one of the most commonly affected joints and patients present with a combination of pain, deformity, inflammation, stiffness and muscle atro- phy. With the lack of cure, none surgical treatment is usually directed to symptomatic relief and prevention of functional dysfunctio [3]. One such treatment modality is pulsed electromagnetic field therapy, that uses electromagnetic fields with an on-off effect of pulsing to produce athermal effects that promote tissue healing and relieve pain and inflammation [4]. Despite the lack of knowledge 
of its effects over placebo, this modality has increased in use significantly over the last 25 years [4].

There has been some analysis of the data regarding the effectiveness of pulsed electromagnetic fields (PEMF) with knee osteoarthritis patients. Marks et al [3] published a literature review on the effects on knee osteoarthritis of both pulsed and continuous shortwave diathermy. The equivocal results of this review were attributed, in part, to the poor methodological quality of the 11 non-randomised comparative and randomised controlled trials (RCTs) they studied. Hulme et al. [5] published a Cochrane review, in 2001. They identified only 3 papers, of adequate quality for review, totalling 259 patients, and concluded there was a lack of evidence of a clinically important effect of PEMF in the treatment of knee osteoarthritis.

We have become aware of several prospective randomised controlled trials comparing PEMF to placebo PEMF, in the treatment of knee osteoarthritis. Thus, we undertook a systematic review of the studies published in the last 10 years to specifically evaluate PEMF for patients with knee osteoarthritis.

\section{Methods}

We performed a similar search strategy to that used by Hulme et al 2001 [5] with the following criteria for inclusion in the review.

\section{Types of studies}

1. Randomised controlled trials

\section{Controlled clinical trials}

Trials were not included if they measured bone and cartilage repair from electromagnetic therapy following a specific treatment for osteoarthritis, which would then no longer be applicable to all knee OA patients.

\section{Types of participants}

Those trials with subjects over 18 years of age, with clinical and radiological confirmation of the diagnosis were considered.

\section{Types of intervention}

All types of PEMF and Pulsed Electrical Stimulation trials were included. Although the latter relies on direct application of an electrical field rather than creating induced current through magnetic impulses, they act by the same mechanism. Trials that compared the intervention group using PEMF to a standard treatment were included, as well as placebo-controlled studies.

\section{Outcomes}

The main outcomes of interest were pain and functional disability as recorded by validated self report instruments such as the Western Ontario and McMasters University Osteoarthritis Index WOMAC [6], EuroQol [7], Arthritis Impact Measurement Scale AIMS[8] or SF-36 [9]. Studies that did not utilise validated outcome measures of pain and function were excluded.

We searched MEDLINE, AMED, EMBASE, HealthSTAR, CINAHL, PEDro, and SPORTDiscus and the Cochrane Controlled Trials Register (CCTR) from January 1966 to September 2005. The electronic search was complemented by the following hand searches of bibliographic references and abstracts published in special issues of specialized journals or in Conference Proceedings. Reference lists were hand-search for further identification of published work, presentations at scientific meetings and personal communications. Abstracts were not used if additional data could not be obtained. The publication bias could not be assessed due to the small number of included studies.

Search strategy

1 exp osteoarthritis/or osteoarthritis.tw.

2 electromagnetics.mp. or electromagnetic fields/[mp = title, abstract, registry number word, mesh subject heading]

3 electromagnetic $\$ . t w$.

4 exp electric stimulation therapy/

5 electrical stimulation.tw.

6 or $/ 2-5$

71 and 6

\section{Assessing quality}

Abstracts were read to make the final decision on selection of the full paper for review. The quality of the papers was assessed by two reviewers independently using a validated criteria checklist[10]. The maximum total score achievable was 5. Any differences were resolved by discussion between the reviewers. Differences unresolved in this manner were resolved in discussion with a third reviewer.

\section{Statistical analysis}

For pain and functional outcomes, weighted mean differences and standardised mean differences, with 95\% confidence intervals, were calculated. Due to differences in follow up assessment timings, data were analysed from the immediate post-intervention assessments. A priori it 
was decided that an effect size difference in post treatment scores of greater than 0.2 was required to represent a clinically important difference. Effect sizes were calculated by dividing the difference in post-treatment group mean scores by the pooled standard deviation of both baseline scores.

\section{Results}

The literature searches produced 20 randomised controlled trials and 5 non randomised clinical trials. Abstracts were viewed to exclude duplicate publications, narrative reviews, letters, commentaries, use of electrical stimulation that was not PEMF, pathologies other than knee osteoarthritis and non-randomised trials. Three studies, reported in previous systematic reviews were excluded due to their use of non-validated outcome measures [11-13]. As a result, five papers were found that met the review selection criteria. These were all RCTs with placebo controlled PEMF. All these trials used both a pain scale and a measure of self reported functional status. The five trials provided data for a total of 276 patients with knee osteoarthritis.

Two studies used low frequency PEMF ranging from 3 to $50 \mathrm{~Hz}$ requiring long durations of treatment (3 to 10 hours a week) $[14,15]$ whilst three studies used typical "pulsed short wave", high frequency devices with shorter treatment durations [16-18]. The low frequency, long duration treatments showed a greater trend for short-term improvement in WOMAC function score than the high frequency, low duration treatments but an equivocal lack of benefit in pain relief.

The highest score for study quality was $5 / 5$ [19] with the lowest being $3 / 5$ [15]. See Table 1 . The weighted mean differences for improvement in pain and function were extremely small and well below the levels one might consider clinically significant. The weighted mean confidence intervals included the null value, for both outcomes, pain 0.66 (95\%CI 0.35 to -1.67$)$, function 0.70 (0.52 to -1.92) See Figure 1. Effect sizes were not statistically or clinically significant for all outcomes with the exception of function in one study, with a low quality score (3/5), (effect size for Function $0.59,95 \% \mathrm{CI} 0.14$ to 1.12 ) [15].

\section{Discussion}

It is unusual for a rehabilitation electrotherapeutic modality to be evaluated in a series of RCTs and thus to find a number of randomised controlled trials of intervention versus control was encouraging. The findings of this review support and update the work of previous reviewers [5]. Despite relatively low total patient numbers $(n=276)$ and some heterogeneity in the frequency of the PEMF used, it would appear that PEMF has little clinical value in reducing the pain of knee osteoarthritis. The assertion that PEMF has no clinically significant benefit, above that

Table I: A table showing the methodological score, numbers, duration of treatment, outcomes measures and standardised mean difference for pain and function

\begin{tabular}{|c|c|c|c|c|c|c|c|c|}
\hline Author & $\begin{array}{c}\text { Quality } \\
\text { Score[I0] (0- } \\
5)\end{array}$ & $\begin{array}{l}\text { Number } \\
\text { receiving } \\
\text { PEMF }\end{array}$ & $\begin{array}{l}\text { Number } \\
\text { receiving } \\
\text { placebo }\end{array}$ & $\begin{array}{l}\text { Duration of } \\
\text { Treatment } \\
\text { (weeks) }\end{array}$ & $\begin{array}{c}\text { Pain } \\
\text { Outcome }\end{array}$ & $\begin{array}{l}\text { Functional } \\
\text { Outcome }\end{array}$ & $\begin{array}{c}\text { Standardised } \\
\text { Mean } \\
\text { Difference for } \\
\text { pain }(95 \% \mathrm{Cl})\end{array}$ & $\begin{array}{l}\text { Standardised } \\
\text { Mean } \\
\text { Difference for } \\
\text { function } \\
(95 \% \mathrm{Cl})\end{array}$ \\
\hline $\begin{array}{c}\text { Klaber- } \\
\text { Moffett et al } \\
\text { 1996[16] }\end{array}$ & 5 & 26 & 22 & 3 & $\begin{array}{l}\text { VAS Pain } \\
\text { Scale }\end{array}$ & $\begin{array}{l}\text { None } \\
\text { reported }\end{array}$ & $\begin{array}{c}-0.03(-0.59 \\
\text { to } 0.54)\end{array}$ & $\begin{array}{l}\text { None } \\
\text { reported }\end{array}$ \\
\hline $\begin{array}{l}\text { Pipetone et al } \\
2001[14]\end{array}$ & 5 & 34 & 35 & 6 & $\begin{array}{l}\text { WOMAC } \\
\text { Pain Scale }\end{array}$ & $\begin{array}{l}\text { WOMAC } \\
\text { Physical } \\
\text { Function } \\
\text { Scale }\end{array}$ & $\begin{array}{c}-0.10(-0.58 \\
\text { to } 0.37)\end{array}$ & $\begin{array}{c}-0.33(-0.80 \\
\text { to } 0.15)\end{array}$ \\
\hline $\begin{array}{l}\text { Thamsborg et } \\
\text { al 2005[15] }\end{array}$ & 3 & 42 & 41 & 6 & $\begin{array}{l}\text { WOMAC } \\
\text { Pain scale }\end{array}$ & $\begin{array}{l}\text { WOMAC } \\
\text { Physical } \\
\text { Function } \\
\text { Scale }\end{array}$ & $\begin{array}{c}-0.31(-0.74 \\
\text { to } 0.12)\end{array}$ & $\begin{array}{c}-0.58(-1.02 \\
\text { to }-0.14)\end{array}$ \\
\hline $\begin{array}{l}\text { Laufer et al } \\
2005[17]\end{array}$ & 3 & 27 & 31 & 3 & $\begin{array}{l}\text { WOMAC } \\
\text { Pain scale }\end{array}$ & $\begin{array}{l}\text { WOMAC } \\
\text { Physical } \\
\text { Function } \\
\text { Scale }\end{array}$ & $\begin{array}{l}-0.05(-0.57 \\
\text { to } 0.46)\end{array}$ & $\begin{array}{c}-0.09(-0.60 \\
\text { to } 0.43)\end{array}$ \\
\hline $\begin{array}{l}\text { Callaghan et } \\
\text { al } 2005[18]\end{array}$ & 4 & 9 & 9 & 2 & $\begin{array}{l}\text { VAS Pain } \\
\text { Scale }\end{array}$ & AIMS & $\begin{array}{c}-0.33(-1.26 \\
\text { to } 0.61)\end{array}$ & $\begin{array}{c}0.00(-0.92 \text { to } \\
0.92)\end{array}$ \\
\hline TOTAL & & 138 & 138 & & & & $\begin{array}{c}-0.16(-0.39 \\
\text { to } 0.08)\end{array}$ & $\begin{array}{c}-0.33(-0.59 \\
\text { to }-0.07)\end{array}$ \\
\hline
\end{tabular}

VAS - Visual analogue scale,

WOMAC - Western Ontario and McMaster's Universities OA index AIMS - Arthritis Impact Measurement Scale 


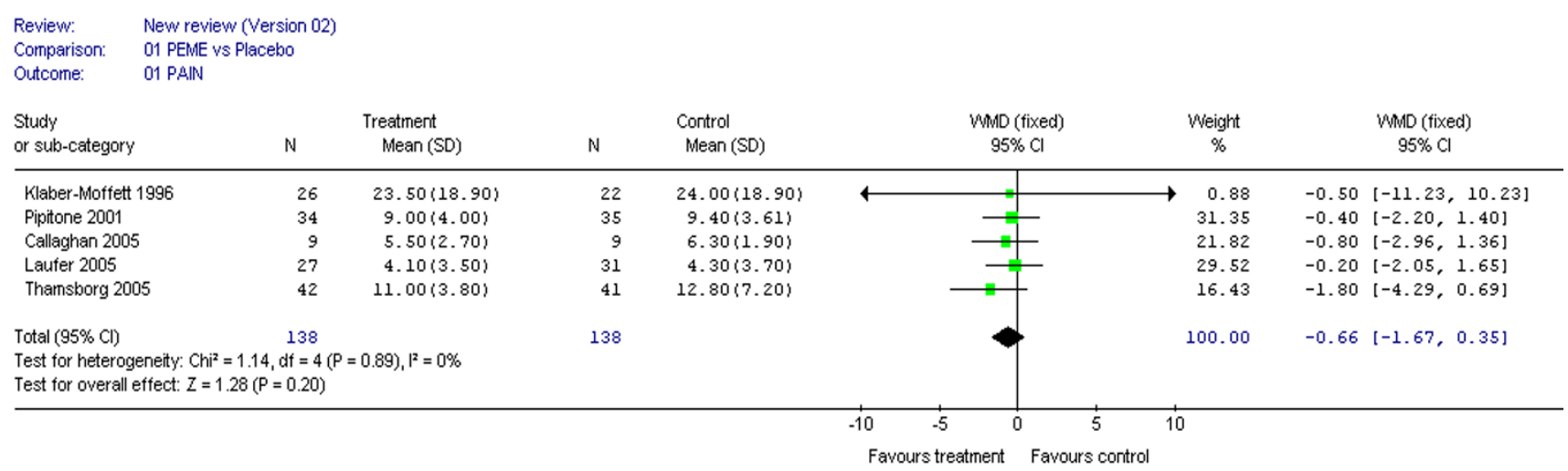

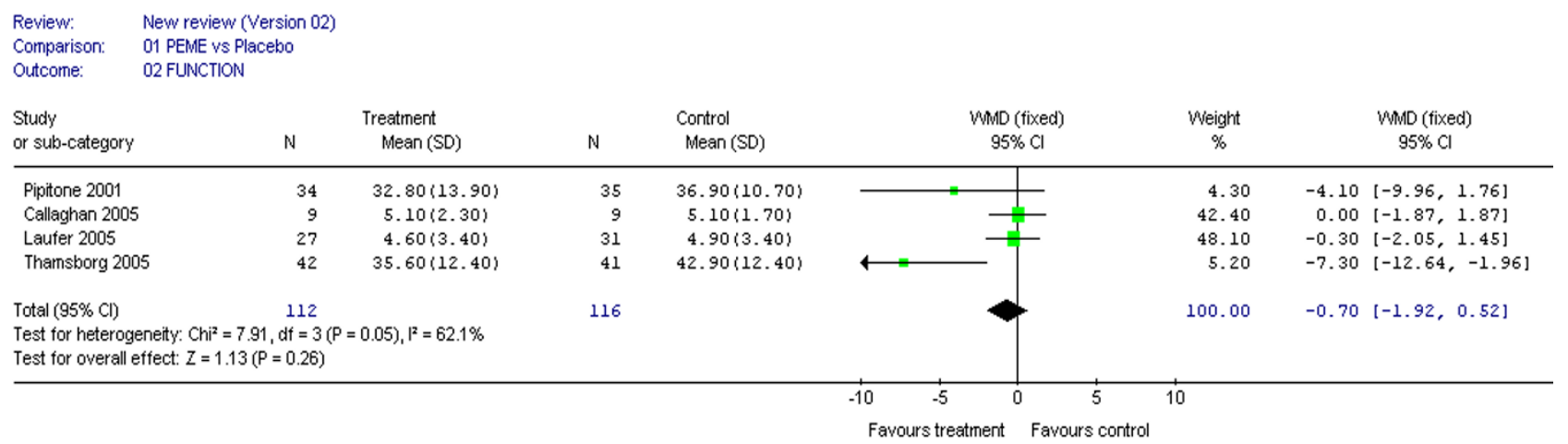

Figure I

Plots of weighted mean difference for pain and functional disability. PEMF versus placebo PEMF ( $95 \%$ confidence intervals).

achieved with placebo treatment, on the pain of patients with knee osteoarthritis can be confidently proposed. An improvement in WOMAC physical function score was described by one study, however this study had a low methodological score and used a unique PEMF device, unreplicated by other studies. The same study did not report an improvement in pain [15].

\section{Conclusion}

Current evidence would suggest that PEMF is unlikely to be a valuable contributor to multimodal rehabilitation of knee osteoarthritis. The resources currently being used for the provision of PEMF may be better utilised in the deployment of more clinically efficacious rehabilitation, such as in the provision of exercise classes and advice sessions $[20,21]$.

\section{References}

I. Spector TD, Hart DJ: How serious is knee osteoarthritis? Ann Rheum Disease 1992, 5 I: I I05-I I06.
2. Woolf $A D$, Pfleger $B$ : Burden of major musculoskeletal conditions. Bulletin of the World Health Organisation 2003, 81:646-656 [http://PM:I47I0506].

3. Marks R, Ghassemi M, Duarte R, Van Nguyen JP: Review of the literature on shortwave diathermy as applied to osteo-arthritis of the knee. Physiotherapy 1999, 85:304-316.

4. Van Nguyen JP, Marks R: Pulsed electromagnetic fields for treating osteoarthritis. Physiotherapy 2002, 88:458-470.

5. Hulme JM, Judd MG, Robinson VA, Tugwell P, Wells G, de Bie RA: Electromagnetic fields for the treatment of osteoarthritis. The Cochrane Library (Oxford) ** 2005;(2): (ID \#CD003523) 2002.

6. Bellamy N, Buchanan WW, Goldsmith CH, Campbell J, Stitt LW: Validation study of WOMAC: a health status instrument for measuring clinically important patient relevant outcomes to antirheumatic drug therapy in patients with osteoarthritis of the hip or knee. J Rheumatol 1988, I 5:1833-1840.

7. Centre for Health Economics University of York: EuroQol EQ-5D: User guide Version B edition. Centre for Health Economics, University of York; 1998.

8. Meenan RF, Gertmen PM, Mason M B: Measuring health in arthritis: the Arthritis Impact Measurement Scales. Arthritis and Rheumatism 1980, 23:146-152.

9. Ware JE, Snow K, Kosinski M, Gandek B: SF-36 health survey manual and interpretation guide Boston, New England Medical Centre; 1993.

10. Jadad AR, Moore RA, Carroll D, Jenkinson C, Reynolds DJ, Gavaghan DJ, McQuay HJ: Assessing the quality of reports of randomized 
clinical trials: is blinding necessary? Control Clin Trials 1996, I7:I-I2.

II. Trock DH, Bollet AJ, Dyer RH: A double blind trial of the clinical effects of pulsed electromagnetic fields in osteoarthritis. J Rheumatology 1993, 20:456-460.

12. Trock DH, Bollet AJ, Markoll R: The effect of pulsed electromagnetic fields in the treatment of osteoarthritis of the knee and cervical spine. Report of randomized, double blind, placebo controlled trials. J Rheumatol 1994, 21:1903-1911.

13. Zizic TM, Hoffman KC, Holt PA, Hungerford DS, O'Dell JR, Jacobs MA, Lewis CG, Deal CL, Caldwell JR, Cholewczynski JG, .: The treatment of osteoarthritis of the knee with pulsed electrical stimulation. J Rheumatol 1995, 22:1757-176I.

14. Pipitone N, Scott DL: Magnetic pulse treatment for knee osteoarthritis: a randomised, double-blind, placebo-controlled study. Curr Med Res Opin 200I, 17:190-196.

15. Thamsborg G, Florescu A, Oturai P, Fallentin E, Tritsaris K, Dissing S: Treatment of knee osteoarthritis with pulsed electromagnetic fields: a randomized, double-blind, placebo-controlled study. Osteoarthritis Cartilage 2005, 13:575-58I.

16. Klaber Moffett JA, Richardson PH, Frost H, Osborn A: A placebo controlled double blind trial to evaluate the effectiveness of pulsed short wave therapy for osteoarthritic hip and knee pain. Pain 1996, 67:127.

17. Laufer Y, Zilberman R, Porat R, Nahir AM: Effect of pulsed shortwave diathermy on pain and function of subjects with osteoarthritis of the knee: a placebo-controlled double-blind clinical trial. Clin Rehabil 2005, 19:255-263.

18. Callaghan MJ, Whittaker PE, Grimes S, Smith L: An evaluation of pulsed shortwave on knee osteoarthritis using radioleucoscintigraphy: a randomised, double blind, controlled trial. Joint Bone Spine 2005, 72:150-I55.

19. McCarthy CJ, Mills PM, Pullen R, Roberts C, Silman A, Oldham JA: Supplementing a home exercise programme with a classbased exercise programme is more effective than home exercise alone in the treatment of knee osteoarthritis. Rheumatology 2004, 43:880-886.

20. Roddy E, Zhang W, Doherty M, Arden NK, Barlow J, Birrell F, Carr A, Chakravarty K, Dickson J, Hay E, Hosie G, Hurley M, Jordan KM, McCarthy C, McMurdo M, Mockett S, O'Reilly S, Peat G, Pendleton A, Richards S: Evidence-based recommendations for the role of exercise in the management of osteoarthritis of the hip or knee--the MOVE consensus. Rheumatology (Oxford) 2005, 44:67-73.

\section{Pre-publication history}

The pre-publication history for this paper can be accessed here:

http://www.biomedcentral.com/1471-2474/7/51/prepub

\section{Publish with Bio Med Central and every scientist can read your work free of charge}

"BioMed Central will be the most significant development for disseminating the results of biomedical research in our lifetime. "

Sir Paul Nurse, Cancer Research UK

Your research papers will be:

- available free of charge to the entire biomedical community

- peer reviewed and published immediately upon acceptance

- cited in PubMed and archived on PubMed Central

- yours - you keep the copyright
BioMedcentral 